\title{
LEGAL INSTRUMENTS IN THE REFORM TREATY - SIMPLIFIED?
}

\author{
Tamara Ćapeta*
}

Summary: This article deals with the new provisions devoted to EU legal instruments proposed by the Constitutional Treaty and the Reform Treaty. In the first part, the changes proposed by the Constitutional Treaty and the Reform Treaty are explained in relation to the present organisation of legal instruments. Besides describing the proposed changes, an attempt is made to identify the motives behind them. In the second part, the proposed changes are assessed as to whether they represent simplifications that would make it easier for European citizens to understand the EU system. The article looks at whether different aspects of the proposed changes, such as decreasing the number of legal instruments, changing their names, or introducing a distinction between legislative and non-legislative acts, represent simplifications. The overall conclusion which follows is that the Reform Treaty does not simplify EU legal acts for EU citizens, even if there are certain changes which might be called simplifications.

\section{Introduction}

Compared to the Treaties currently in force, the Reform Treaty ${ }^{1}$ proposes certain changes in the organisation of the legal acts whereby EU institutions decide. Proposals for introducing changes in Treaty provi-

\footnotetext{
* Professor of EU Law at the University of Zagreb Faculty of Law.

1 The Reform Treaty is an attempt to end the constitutional crisis in Europe created by the negative perception on the part of some European citizens of the idea of having a document called 'the Constitution' as the highest law governing the new polity. The green light for the Reform Treaty was given at the European Council that ended Germany's presidency of the EU (held on 21 and 22 June 2007), at which Chancellor Merkel broke a deal on the Treaty. The European Council framed a relatively clear mandate for the Portuguese presidency regarding the acceptable content of the new Treaty to be formally submitted to the Intergovernmental Conference. See IGC Mandate, published as Annex I to Council of the European Union, 'Presidency Conclusions' (Brussels, 20 June 2007) 11177/07 CONCL 2

<http://www.consilium.europa.eu/ueDocs/cms_Data/docs/pressData/en/ec/94932. pdf $>$ accessed 27 July 2007. The Portuguese presidency prepared a draft of the Treaty and submitted it to the IGC. The first published version, in French, can be found at: <http://www.consilium.europa.eu/uedocs/cmsUpload/cg00001.fr07.pdf> accessed 27 July 2007. The English version of the Draft Reform Treaty has been published at:

<http://www.consilium.europa.eu/uedocs/cmsUpload/cg00001.en07.pdf> accessed 1 August 2007. A consolidated version of the TEU, prepared by Steve Peers of the University of Essex, is now also available at: <http://www.statewatch.org/euconstitution.htm> accessed 30 July 2007.
} 
sions on legal acts have been on the European agenda for some time. ${ }^{2}$ However, they have usually been hidden behind other, more vocal political issues, such as voting in the Council. It was not, therefore, until the text of the Constitutional Treaty ${ }^{3}$ was adopted that any amendment to the Treaties in this respect was formally accepted. The Constitutional Treaty proposed significant changes in the organisation of EU legal instruments, but has never seen the light of the day, since it was rejected by French and Dutch citizens at their referenda, and has thus never achieved legal significance. Most of its substance was, however, transferred to the new project for amendments to the European Union architecture, known under the name of the Reform Treaty. ${ }^{4}$ Some differences may, nevertheless, be identified. One of them concerns the way in which legal instruments are to be reformed.

The most important reason for undertaking a reorganisation of EU legal acts is their simplification. ${ }^{5}$ Simplification, however, can mean many things, and may serve different goals. A common definition of the word simple is 'easily understandable to everyone'. Simplifying may, therefore, mean making things comprehensible to the public. Indeed, this was one of the meanings that Working Group IX on Simplification did give to the

2 The European Parliament proposed introducing a hierarchy of Community acts in its Resolution on the Draft Treaty establishing the European Union [1984] OJ C77/53. This issue was also raised during the IGC that led to the adoption of the Maastricht Treaty, when the European Parliament proposed a differentiation between legislative and regulatory acts in its Resolution on the Nature of Community Acts [1991] OJ C129/136. In 1991 similar proposals were also put on the table by the European Commission. These initiatives ended with the adoption of Declaration No 16 on the hierarchy of Community acts, annexed to the Maastricht Treaty, which invited the next IGC, scheduled for 1996, to "examine to what extent it might be possible to review the classification of Community acts with a view to establishing an appropriate hierarchy between the different categories of act'. Once again, although the European Parliament and the Commission, as well as some Member States, have introduced such proposals, and this topic was also discussed by the Reflection Group preparing the Conference, no proposal to amend the Treaties with regard to legal acts was finally adopted. For more see R Kovar, 'La Déclaration No 16 annexée au Traité sur l'Union européenne: chronique d'un échec annoncé?' [1997] 1-2 CDE 3; see also R Bieber and I Salomé, 'Hierarchy of norms in European Law' [1996] 33 CMLRev 907.

3 The Constitutional Treaty was officially entitled the Treaty establishing a Constitution for Europe, and the version submitted to the Member States for ratification was published on 16 December 2004 (OJ C310).

4 The UK-based eurosceptic think-tank called Open Europe published an analysis according to which $96 \%$ of the new text is the same as that of the failed Constitution <http://www. openeurope.co.uk> accessed 26 July 2007. See also 'Just like the constitution, say friends and foes of new EU treaty' EUobserver (24 July 2007) <http://www.euobserver.com> accessed 24 July 2007.

5 See, for instance, the Laeken Declaration attached to Council of the European Union, 'Presidency Conclusions' (Laeken, 14 - 15 December 2001) SN 300/1/01 REV 1 p 22. The Convention working group established to propose a reorganisation of EU legal instruments and procedures in the Constitutional Treaty was called Working Group IX on the Simplification of Legislative Procedures and Instruments. 
term. ${ }^{6}$ Citizens' ability to understand the EU system was seen as a precondition for democracy in the EU, as citizens cannot criticise and control a system which they do not understand.

Simplification can, however, also occur by trying to explain, in as simple a way as possible, an otherwise complex EU reality, or it may mean changing this complex reality itself. In other words, simplification can either mean making a legal text match reality, or it can mean something more than that: adjusting not only the legal text, but also the reality. Both of these methods can lead to a better understanding of how the system functions.

This paper aims to discuss whether the proposals of the Constitutional Treaty and the Reform Treaty concerning legal acts represent simplifications. It will also attempt to examine whether these proposals seek only to adjust legal texts, or actually to change the EU reality itself. As there are some differences between the Constitutional Treaty and the Reform Treaty regarding the organisation of legal acts, the paper also analyses whether these differences are substantive or only nominal, and what the reasons for them are. The paper is divided into two parts. In the first, changes in relation to the present situation, proposed first by the Constitutional Treaty and more recently by the Reform Treaty, are explained. In the second part, the question of whether particular elements of these proposed changes represent simplifications for EU citizens is assessed.

\section{The Present Situation and Proposals in the Constitutional Treaty and the Reform Treaty}

\section{The current Treaties}

According to the Treaties currently in force, EU institutions use different sets of legal instruments in different pillars. ${ }^{7}$ In addition to the 15 different legal instruments envisaged by the Treaties, ${ }^{8}$ there are other legal instruments which, although not contained therein, also form part of EU law, as determined by the European Court of Justice (ECJ) in the

\footnotetext{
6 Working Group IX on Simplification, 'Final Report' (29 November 2002) CONV 424/02 pp 1-2.

7 Within the first pillar, institutions may use regulations, directives, decisions, recommendations and opinions, as defined in Art 249 TEC. In the second pillar (Common Foreign and Security Policy), institutions may set principles and general guidelines, as well as adopt common strategies, joint actions and common positions, as envisaged by Art 12 TEU. In the third pillar (Police and Judicial Cooperation in Criminal Matters), institutions may issue common positions, framework decisions, decisions and conventions, according to Art 34 TEU.

8 As counted by Working Group IX on Simplification (n 6) 3. See also European Convention (Secretariat), 'The legal instruments: present system' (Note) CONV 50/02, 15 May 2002.
} 
ERTA case..$^{9}$ These legal acts are defined functionally; that is, the Treaties define legal acts only in terms of their legal effects, which, in turn, reflect the function of each act within the Treaty scheme. Thus, for instance, a first-pillar regulation is generally and directly applicable in all Member States, reflecting its purpose of unifying different internal norms in Member States by replacing them with a single Community norm. On the other hand, a directive binds Member States as to the regulatory result, but leaves them a certain freedom as to how to achieve it, thus reflecting a directive's purpose of harmonising rather than unifying law. ${ }^{10}$

Any EU institution with law-making powers may adopt any of the acts enumerated in the Treaties. ${ }^{11}$ These acts are, therefore, currently distinct from the institution enacting them. In order to know whether a directive was enacted by the Council, the Council and the Parliament together, or the Commission, one needs to look at the directive itself. Likewise, legal instruments are distinct from the procedure whereby they may be adopted. Any of the legislative procedures provided for by the Treaties may result in the adoption of any of the acts envisaged therein, depending only on the specific legal basis giving the EU/EC the power to act in a certain field. ${ }^{12}$ Implementing acts bearing the same name are

9 Case 22/70 Commission v Council [1971] ECR 263. In that case, the Court considered the proceedings of the Council to be a legally binding instrument subject to judicial review. The Court also considered other non-Treaty acts to be part of Community law and to have a legally binding force: a Commission communication in Case C-325/91 France $v$ Commission [1993] ECR I-3283 para 23 and in Case C-57/95 France $v$ Commission [1997] ECR I-1627 para 23; a Code of Conduct enacted by the Commission in Case C-303/90 France $v$ Commission [1991] ECR I-5315 para 25; or a Resolution of the Council in Case 32/79 Commission $v$ UK [1980] ECR 2403 para 11. Whether a non-Treaty act has a legally binding force is a matter of substantive analysis of the act in question. In this respect, see Case C-57/95 France $v$ Commission para 9.

10 Even if it is often asserted that the case law on the direct effect of directives has blurred the distinction between directives and regulations, it has not really changed the difference in purpose of these two acts. Precisely because its purpose is harmonisation, rather than unification, only rarely will the provisions of a directive satisfy the conditions necessary for direct effect, primarily because they leave it to the Member States to make a substantive choice as to the appropriate measures for achieving the desired result. If their difference is blurred, therefore, it is not due to the doctrine of the direct effect of directives, but rather to the (incorrect) decision by EU institutions to regulate certain areas in a detailed manner by way of directives.

11 This is especially true of the first pillar, while second-pillar acts are more closely tied to the enacting institution (the European Council or the Council) than first-pillar acts.

12 There are certain legal bases which do not allow institutions to choose a legal instrument, but rather prescribe the available legal instrument in advance. Thus Art 89 TEC enables the Council only to adopt regulations. Other articles require only directives, eg Art 47 TEC (mutual recognition of diplomas), Art 52 TEC (liberalisation of services), Art 94 TEC (approximation of laws necessary for the establishment and functioning of the internal market; but see Art 95 which allows a choice of acts for the same purpose), Art 96 TEC (elimination of distortions of competition), and Art 137 TEC (minimum requirements in certain issues related to social policy). 
also adopted, either by the Commission in the comitology procedure, or by the Council. In these cases, the Treaties do not prescribe a procedure for their adoption. ${ }^{13}$

Thus, at present, the legal acts envisaged by the Treaties do not reflect the division of competences between EU institutions. At the same time, this horizontal division of competences is not governed by any general principle covering the entire range of EU powers; rather, the relationship between institutions depends on the area of competence or policy involved, and is to be interpreted in light of the relevant Treaty articles in each case. One consequence of this is that no pre-established hierarchy exists among EU institutions, such that an act adopted by a 'higher' institution would have a higher status than one adopted by a 'subordinate' institution. This has been clearly confirmed by the ECJ. In France, Italy and the UK $v$ Commission, for example, the ECJ replied as follows to the UK's arguments that directives adopted by the Commission are not of the same nature as those adopted by the Council: ${ }^{14}$

There is, however, no basis for that argument in the Treaty provisions governing the institutions. According to Article 4, the Commission is to participate in carrying out the tasks entrusted to the Community on the same basis as the other institutions, each acting within the limits of the powers conferred upon it by the Treaty. Article 155 provides, in terms which are almost identical to those used in Article 145 to describe the same function of the Council, that the Commission is to have its own power of decision in the manner provided for in the Treaty. Moreover, the provisions of the chapter which lays down general rules concerning the effects and content of measures adopted by the institutions, in particular those of Article 189, do not make the distinction drawn by the United Kingdom between directives which have general application and others which lay down only specific measures. According to the first paragraph of that Article, the Commission, just as the Council, has the power to issue directives in accordance with the provisions of the Treaty. It follows that the limits of the powers conferred on the Commission by a specific provision of the Treaty are to be inferred not from a general principle, but from an interpretation of the particular wording of the

13 The comitology procedure was introduced by secondary law, and is today based on Council Decision 1999/468 of 28 June 1999 laying down the procedures for the exercise of implementing powers conferred on the Commission [1999] OJ L184/23.

14 The UK argument was based on the implied superiority of the Council over the Commission, as the Council was given a 'legislative' role by the Treaties, while the Commission had only an executive role. See Joined Cases 188-190/80 France, Italy and the UK $v$ Commission [1982] ECR 2545 para 5. 
provision in question, in this case Article 90, analyzed in the light of its purpose and its place in the scheme of the Treaty. ${ }^{15}$

Thus, under the present Treaties, there is neither a hierarchy between EU institutions, nor a pre-established hierarchy between legal acts. This does not mean, however, that there is no hierarchy between legal acts at all. Rather, it is clear that acts adopted on the basis of another act must comply with the enabling act. ${ }^{16}$ Whether the implementing act complies with the enabling act is decided based on a case-by-case interpretation of the substance of each. ${ }^{17}$

\section{The Constitutional Treaty}

The Constitutional Treaty proposed significant changes in the organisation of EU legal acts. The provisions on legal acts were found in its Part I, ${ }^{18}$ under Title V: 'Exercise of Union Competence'. Such placement in the first and 'most constitutional' part of the Treaty gives an idea of the great importance attributed to issues related to the organisation of legal acts. This is particularly true if one considers that these acts had previously been regulated almost sporadically in less prominent parts of the Treaties. The text was largely, but not entirely, the result of proposals by Working Group IX of the Convention preceding the 2004 IGC, ie the working group charged with the task of simplifying EU legal acts.

\footnotetext{
15 Joined Cases 188-190/80 France, Italy and the UK $v$ Commission (n 14) para 6. Art 145 is now Art 202 TEC; Art 155 is Art 211 TEC; Art 189 is Art 249 TEC; and Art 90 is Art 86 TEC. See also Case C-163/99 Portugal v Commission [2001] ECR I-2613 paras 21 and 23.

16 It is not clear, however, whether the validity of an act that implements another, basic act can be affected by its incompatibility with some other act adopted directly pursuant to the Treaty. For a short overview of different positions, see R Schütze, 'Sharpening the Separation of Powers through a Hierarchy of Norms?' (2005) EIPA Working Paper 2005/W/01 p 8. Some authors consider the hierarchy between basic and implementing acts to be merely relative; see J Bast, 'On the Grammar of EU Law: Legal Instruments' (2003) Jean Monnet Working Paper 9 p 25

<http://www.jeanmonnetprogram.org/papers/03/030901-05.pdf> accessed 24 July 2007. Others argue that such 'tertiary law' should conform to the entire 'secondary law', ie those norms adopted directly pursuant to the Treaty; see K Lenaerts and A Verhoven, 'Towards a legal framework for executive rule-making in the EU? The contribution of the Comitology Decision' [2000] 37 CMLRev 645, 652.

17 For example, Case 25/70 Einfuhr- und Vorratsstelle für Getreide und Futtermittel $v$ Köster et Berodt \& Co [1970] ECR 1161 and Case 230/78 SpA Eridania-Zuccherifici nazionali and SpA Società Italiana per l'Industria degli Zuccheri v Minister of Agriculture and Forestry, Minister for Industry, Trade and Craft Trades and SpA Zuccherifici Meridionali [1979] ECR 2749.

18 The Constitutional Treaty was organised in four parts, Part I containing the most important provisions for the EU's organisation and functioning, Part II the EU Charter of Fundamental Rights, and Part III other provisions of the TEU and TEC as amended, while Part IV contained some final provisions common to all the other parts.
} 
Altogether seven articles ${ }^{19}$ were inserted into Part I of the Constitutional Treaty in order to explain EU legal instruments.

The new system contained several novelties. Firstly, the acts were renamed so that, instead of 'regulation' and 'directive', the Constitutional Treaty introduced the terms 'law' and 'framework law'. However, in terms of the legal effects of these acts, the definition still corresponded to the familiar division between regulations and directives. ${ }^{20}$ Thus a law was defined as an act of general application, binding in its entirety and directly applicable in all Member States, while a framework law was defined as an act binding upon each Member State to which it is addressed as to the result to be achieved, but leaving it to the national authorities to choose the form and methods of achieving it. The term 'regulation' still figured among the acts, but was differently defined. Under the Constitutional Treaty, a regulation could have the same effects as either a regulation or a directive under the present EC Treaty. Finally, the term 'decision' was also retained, but with a broader definition as to its legal effects than that of a current first-pillar decision. A decision was thus defined as binding in its entirety and, where its addressees are specified, as binding only on them. The adjective 'European' was attached to all four types of legally binding acts: European law, European framework law, European regulation, and European decision. ${ }^{21}$

Secondly, the number of acts available to EU institutions was reduced. Since the Constitutional Treaty eliminated the division of EU powers into three pillars, although the CFSP remained an intergovernmental power, the same legal acts were to be used for all powers of the EU. Thus the overall number of acts available under the Constitutional Treaty decreased, ${ }^{22}$ while at the same time the difference between types of powers was not reflected in these acts.

Finally, the Constitutional Treaty introduced a division into legislative and non-legislative acts, and further divided non-legislative acts into delegated and implementing acts, thus implicitly introducing a hierarchy among these acts. Legislative acts were defined as those adopted on the basis of legislative procedures. While the Constitutional Treaty proposed that co-decision become the regular legislative procedure, many other procedures were retained and deemed legislative. These procedures,

19 Art I-33 to I-39 of the Constitutional Treaty.

20 In this respect, see S Prechal, 'Adieu à la Directive?' [2005] 1 European Constitutional Law Review 481.

21 Art I-33 of the Constitutional Treaty.

22 The Constitutional Treaty did not eliminate the possibility for institutions to use other, extra-constitutional acts, although it tried to discourage such practices. See Art I-33 para 2 of the Constitutional Treaty. 
which the Constitutional Treaty called 'special legislative procedures', ${ }^{23}$ were those whereby either the European Parliament alone ${ }^{24}$ or the Council alone ${ }^{25}$ adopted legal acts, with some type of participation by the other institution. In the case of regular legislative procedure, the initiator of the legislative act to be adopted was exclusively the European Commission. However, since many special legislative procedures remained intact, the Commission did not enjoy an exclusive power to propose legislative acts, but rather shared that power with the Member States, the European Parliament, the European Central Bank, or even the European Court of Justice and the European Investment Bank. ${ }^{26}$ Thus acts adopted under the ex co-decision procedure or other different legislative procedures were legislative acts. In this way, the adoption of legislative acts was reserved to the European Parliament and the Council. The European Commission, or indeed other EU bodies, could not enact legislative acts.

The Constitutional Treaty opted for a formal definition of a legislative act, coupling this notion only with a certain type of procedure and, consequently, with certain institutions able to enact it. Thus it did not follow the proposal by the Working Group on Simplification, which offered a more substantive understanding of legislative acts, ie acts adopted pursuant to the Treaty and containing the essential elements in a given field. ${ }^{27}$ Some connection to this substantive criterion was, however, maintained in the article dealing with delegated acts, which prohibited delegation of these essential elements and reserved them for legislative acts. ${ }^{28}$

\footnotetext{
23 Art I-34 para 2 of the Constitutional Treaty.

24 Art III-330 of the Constitutional Treaty gives Parliament the right to adopt a European law regulating its members' performance of their duties. Such a law would require the consent of the Council. Under Art III-333 of the Constitutional Treaty, Parliament was to adopt a European law regulating exercise of the right of inquiry. Such a law would enter into force upon the consent of both the Council and the Commission. Under Art III-335 of the Constitutional Treaty, Parliament was given the power to regulate the office of the European Ombudsman, having obtained the Commission's opinion and the Council's consent.

25 According to the Constitutional Treaty, the Council may, upon consultation with the European Parliament, unanimously adopt the following: a European law or framework law to regulate the exercise of voting rights in municipal and European elections for non-nationals in their country of residence (Art III-126); a law or framework law to harmonise indirect taxation (Art III-171); a European law regulating language arrangements for European intellectual property rights (Art III-176); decisions on certain issues of social policy (Art III-210(3)); and, in the field of judicial and police cooperation, a European law establishing European Public Prosecutor's Office (Art III-274), a European law or framework law regulating operational cooperation between police authorities (Art III-275(3)), and, finally, a law or framework law setting the conditions under which the judicial and police authorities of one Member State may operate in the territory of another (Art III-277).

26 Art I-34 para 3. See also Art I-26 para 2 of the Constitutional Treaty.

27 Working Group IX on Simplification (n 6) 9.

28 Art I-36 of the Constitutional Treaty.
} 
The division into legislative and non-legislative acts was accompanied by new names for them. Thus legislative acts were called European laws and European framework laws, while binding non-legislative acts were called European regulations and European decisions. Once the names of the legal acts had been modified, they needed to be changed for each specific legal basis throughout the Constitutional Treaty. Thus it was necessary to revise the legal bases authorising institutions to act in Part III of the Constitutional Treaty. At the same time, it was also decided whether an act adopted by the Parliament alone or the Council alone was legislative or non-legislative, and names were given to such acts accordingly. According to many commentators, the way in which this was done was far from satisfactory, as it was not clear by which criteria these decisions were made. ${ }^{29}$

One criterion proposed by Working Group IX for deciding which acts based directly on the Treaty were non-legislative was that such acts only elaborate in detail the policy choices in a particular area that are already expressed in the Treaty. ${ }^{30}$ However, this does not help us in understanding certain choices. For example, the legal basis allowing the Council to enlarge the list of state subsidies deemed compatible with the internal market was classified by the Constitutional Treaty as non-legislative. The Council was to specify categories of aid additional to those already enumerated in the Constitutional Treaty by means of European regulations or decisions. ${ }^{31}$ Yet how can a decision by the Council adding another category of state aid which is deemed permissible under the Treaty be classified as merely a development of existing policy choices, when in fact it represents a change in the policy choice contained in the Treaty, adding a new category to a closed list? Or how can the decisions which the Council may enact in the field of competition law - for example, to define the 'respective functions of the Commission and of the Court of Justice of the European Union' in applying rules on competition - be deemed non-essential? And yet the Constitutional Treaty envisaged that the Council would adopt non-legislative European regulations for this purpose. ${ }^{32}$ There are still other examples, which have been discussed elsewhere. ${ }^{33}$ Suffice it to say here that the criteria for choosing whether a decision would be legislative or non-legislative cannot be deduced from the choices that were actually made. This makes it difficult to understand

\footnotetext{
29 For an excellent analysis, see Jonas Bering Liisberg, 'The EU Constitutional Treaty and Its Distinction between Legislative and Non-Legislative Acts - Oranges into Apples?' (2006) Jean Monnet Working Paper 1. See also M Dougan, 'The Convention's Draft Constitutional Treaty: Bringing Europe closer to its lawyers?' [2003] EL Rev 763, 783-784; K Lenaerts, 'A Unified Set of Instruments' [2005] 1 EuConst 57, 61.

30 Working Group IX on Simplification (n 6) 13.

31 Art III-167(3)e of the Constitutional Treaty.

32 Art III-163 of the Constitutional Treaty.

33 Jonas Bering Liisberg (n 29) 31-44.
} 
the newly proposed division into legislative and non-legislative acts. Finally, as legislative acts may be adopted only by the Council and/or the European Parliament, acts adopted by the Commission directly pursuant to the Treaty were necessarily classified as non-legislative, even if they sometimes involve difficult policy choices. ${ }^{34}$

Besides the distinction between legislative and non-legislative acts, the Constitutional Treaty distinguishes between different types of nonlegislative acts, based on the distinction between delegation and implementation. However, the Constitutional Treaty does not really explain where the difference between the two lies. Article I-36, which deals with delegation, states that legislative acts may delegate power to the Commission to supplement or amend certain non-essential elements of a law or framework law. Article I-37, dealing with implementation, does not try in the same manner to explain what implementation is, but rather specifies to whom implementing powers may be given (the Commission or the Council) and why (if uniform implementing conditions are needed). Implementing powers can, it seems, be given to EU institutions by all legally binding EU acts, and thus not necessarily only by legislative acts.

Implementation obviously does not only mean the application of legal rules to individual situations, as it may be performed by European regulations, which are acts of general application. Therefore, it also implies the adoption of generally applicable rules, which necessarily do, in some way, supplement a basic enabling act. The possibility of supplementing a basic act thus cannot be what constitutes the difference between delegation and implementation, for both may serve to flesh out a basic act. The only substantive difference between delegation and implementation which can be read from the text of the Constitutional Treaty is that the Commission may amend certain 'non-essential' parts of a basic act only when exercising delegated powers, while it may not do so under implementing powers.

The difference, and an important one, lies in the procedure giving a different power of control over the Commission to the enabling institutions, depending on whether it is performing a delegated role or implementing EU rules. In its implementing role, the Commission would continue to be subject to the comitology procedure. ${ }^{35}$ When, on the contrary,

\footnotetext{
34 As in Art III-166(3) of the Constitutional Treaty, relating to public undertakings and undertakings to which states grant special or exclusive rights.

35 In fact, Art I-37 of the Constitutional Treaty does not say this. Rather, it envisages that the control mechanism for the Commission's implementing powers will be enacted by a European law, ie by a joint decision of the European Parliament and the Council. This gives new powers to the European Parliament in organising control over the Commission's implementing role. In theory, the control mechanism introduced by the Comitology Decision ( 13) need not be retained, or may be significantly modified. The two institutions might, on a proposal by the Commission, decide on new forms of control, including those envisaged for control of the Commission's delegated role.
} 
the Commission enacts legal provisions based on delegation, the Constitutional Treaty envisages a different type of control, eg the possibility for the Parliament or the Council to revoke delegated powers, or the option of conditioning the entry into force of a delegated regulation on the consent of the European Parliament and the Council, which would be deemed granted if no objection were raised within a certain period of time. ${ }^{36}$ Thus control over the Commission's delegated powers pertains to the time following the adoption of a delegated act, whereas control over implementing powers relates to the time before, or better stated, during adoption of an implementing act. Prior control over delegated acts might be exercised to a certain extent by the delegating institution(s) in defining the 'objectives, content, scope and duration of delegated power'. ${ }^{37}$

Although the Constitutional Treaty did not connect non-legislative acts with any procedure, its Article I-35 enumerated the institutions empowered to adopt non-legislative acts: the European Council, the Council, the Commission and the European Central Bank. Not all of these institutions could adopt any type of non-legislative act. Thus the European Council could only adopt European decisions, while the other three institutions might adopt both European decisions and European regulations. However, as the Constitutional Treaty introduced the additional distinction between delegation and implementation, both of which are performed by means of non-legislative acts, it is necessary to read other articles in order to understand which institutions could adopt which type of act. Since the power to regulate could be 'delegated' only on the European Commission, and delegated powers only exercised on the basis of European regulations (not decisions), ${ }^{38}$ it may be concluded that only the Commission could be enabled to adopt delegated European regulations. On the other hand, while implementation is usually done by the Member States, ${ }^{39}$ it could, under certain conditions, be entrusted to the EU level, in which case it would be performed, as a rule, by the European Commission, but also by the Council in duly justified specific cases. ${ }^{40} \mathrm{Im}$ plementing acts could take the form either of a European regulation or a European decision. ${ }^{41}$ Thus implementing European regulations and decisions could be adopted by either the Commission or the Council, as well as by the European Central Bank, which, according to the Constitutional

\footnotetext{
36 Art I-36(2) of the Constitutional Treaty.

37 As envisaged in the second sentence of Art I-36 para 1 of the Constitutional Treaty.

38 Art I-36 para 1 of the Constitutional Treaty.

39 Art I-37 para 1 of the Constitutional Treaty.

40 Art I-37 para 2 of the Constitutional Treaty. The precondition for implementation at the European rather than Member State level is that 'uniform conditions for implementing legally binding Union acts are needed'.

41 Art I-37 para 4 of the Constitutional Treaty.
} 
Treaty, could enact European regulations and decisions 'in the specific cases provided for in the Constitution'. ${ }^{42}$

\section{The Reform Treaty}

Unlike the Constitutional Treaty, which was supposed to replace the old text of the Treaties - the TEU and TEC - with a completely new one, the Reform Treaty sticks to the old method of changing the Treaties, ie introducing amendments to the latest version of their text. Once the consolidated texts are produced, the Reform Treaty will result in two treaties: the Treaty on European Union (TEU) and the Treaty on the Functioning of the European Union (ToFEU), which is the new name for the EC Treaty, as amended. The TEU will contain common provisions for the entire EU, plus provisions regulating the Common Foreign and Security Policy. The ToFEU will contain provisions relating to other EU policies, including issues which previously belonged to the third pillar, eg police and judicial cooperation in criminal matters. ${ }^{43} \mathrm{EU}$ institutions will be enumerated and their basic functions within the EU system explained in the TEU, while more detailed provisions on their functioning will be found in the ToFEU. The latter will also contain provisions relating to legislative procedures and legal acts to be adopted by EU institutions.

The Reform Treaty thus places provisions dealing with legal acts in the ToFEU, there where Article 249 TEC is currently located, amending the Article itself and inserting several new articles after it. Even though the two new treaties have the same legal force, ${ }^{44}$ the TEU is still more general, setting forth the most important features of the EU in its first part. At first glance, therefore, one may conclude that the issue of legal acts has been given less importance in this reform, compared with the Constitutional Treaty project. The legal acts that EU institutions may adopt are not even enumerated in the amended TEU, although this would have been possible even within the limits imposed by this method of changing the Treaties. ${ }^{45}$ One additional constraint, however, was the mandate given by the Brussels European Council of 21 and 22 June 2007. ${ }^{46}$

\footnotetext{
42 Art I-35 para 2 of the Constitutional Treaty.

43 Thus one may say that the Reform Treaty has created a two-pillar EU in place of a threepillar one.

44 Cf the new Art 1 para 2 ToFEU, as proposed by the Reform Treaty.

45 Thus, for example, the basic definitions of each institution, including its composition and its functions within the Treaty scheme, have been moved from the Treaty on the Functioning of the EU to the Treaty on European Union. See the newly proposed Title III TEU.

46 The part relevant to the restructuring of legal acts reads as follows:

u) In Article 249 (definition of EU acts: regulation, directive and decision), in a new Section 1 on the Union's legal acts, the definition of a decision will be aligned with the one agreed in the 2004 IGC.
} 
The second important difference compared to the Constitutional Treaty is the Reform Treaty's retention of the old names for legal acts. Thus, even if for the wrong reasons, ${ }^{47}$ the terms 'regulation', 'directive' and 'decision' have survived the amendments. This is fortunate, in my opinion, as I will explain later. The definition of a decision has been enlarged, in the same way as in the Constitutional Treaty, so that it may be adopted either with or without specific addressees. ${ }^{48}$

The differentiation between legislative, delegated and implementing acts introduced by the Constitutional Treaty is retained. ${ }^{49}$ As in that Treaty, legislative acts have been defined here formally, as acts adopted in the legislative procedure.$^{50}$ Legislative procedures resulting in a legislative act can, again, be ordinary (ex co-decision) or special (the Council or the Parliament deciding alone, with some participation by the other institution). ${ }^{51}$ Also as in the Constitutional Treaty, the provision dealing with delegated acts ${ }^{52}$ reserves the essential elements of an area of competence to legislative acts, thus introducing substantive elements into the understanding of this term. The substantive difference between delegation and implementation is not explained in the Reform Treaty, either, and the only visible difference seems to be a procedural one regarding the type of control over the Commission's delegated or implementing role.

v) As a consequence of dropping the denominations 'law' and 'framework law', the innovations agreed in the 2004 IGC will be adapted, while maintaining the distinction between what is legislative and what is not and its consequences. Accordingly, after Article 249, three Articles will be introduced on, respectively, acts which are adopted in accordance with a legislative procedure, delegated acts and implementing acts. The Article on legislative acts will state that acts (regulations, directives or decisions) adopted under a legislative procedure (ordinary or special) will be legislative acts. The terminology in the Articles on delegated and implementing acts, as agreed in the 2004 IGC, will be adapted accordingly.

See the IGC Mandate published as part of the Brussels Council Presidency Conclusions (n 1) 22 .

47 It seems that the main reason for dropping the names accepted in the Constitutional Treaty was the insistence of some Member States, led by the UK, that any possible link with statehood be removed from the text of the Treaties. Thus, together with the provisions on European symbols, such as the anthem and flag, or changing the name of the Minister of Foreign Affairs to High Representative, the names 'European law' and 'European framework law' were also dropped.

48 See amended Art 249 ToFEU, as proposed by the Reform Treaty.

49 However, unlike the Constitutional Treaty, there are no titles here for the articles grouping acts as either legislative or non-legislative. There is also no separate article dealing with non-legislative acts together as a group, as proposed by the Constitutional Treaty in its Art I-35. One possible explanation for this is that the names of the acts have not been changed, and do not differ depending on whether the act is legislative or not. On the other hand, there might also be a wish to leave clarification of the meaning of legislative and non-legislative acts and the purpose of such a division to developments in practice.

50 See the new Art 249A para 3 ToFEU, as proposed by the Reform Treaty.

51 See the new Article 249A para 1 and 2 ToFEU, as proposed by the Reform Treaty.

52 See the new Article 249B ToFEU, as proposed by Article 2 - 239) of the Reform Treaty. 
The third difference between the Reform Treaty and the Constitutional Treaty is that any of the legally binding EU acts - regulations, directives or decisions - can be adopted as a legislative act. Thus a decision, which could be adopted only as an implementing act under the Constitutional Treaty, returns among the possible legislative acts in the new Treaty. All three types of legally binding acts can also be adopted as delegated or implementing acts. However, they must be named accordingly: for example, a delegated regulation, or an implementing directive..$^{53}$ Thus it will be possible to know simply by reading the title of a given act whether it is a legislative act or non-legislative one, and whether it was adopted based on delegated or implementing powers, without having to make recourse to the text of either the act itself or the basic enabling act.

As the legislative/non-legislative division is not accompanied by differentiated names of legal acts, as was the case in the Constitutional Treaty, it has not been necessary to revise each specific legal basis in the ToFEU and decide whether an act which the Council or the Parliament is entitled to adopt on its own should be characterised as legislative or non-legislative. In this way, the often unsatisfactory choices made by the Constitutional Treaty ${ }^{54}$ have been avoided. It remains unclear whether certain acts adopted by the Council or the Parliament directly pursuant to the ToFEU are legislative or not. ${ }^{55}$

Finally, the fourth difference lies in how issues of the Common Foreign and Security Policy (CFSP) are dealt with. The Reform Treaty handles acts under the CFSP and under other competences separately. While the provisions regulating legal acts which I have just described do not mention the CFSP area at all, ${ }^{56}$ or indeed the European Council as a possible enactor of legal acts, the part of the Constitutional Treaty dealing with legal acts was clearly relevant to all EU policies, including the CFSP. Thus the Constitutional Treaty envisaged that the European

53 This also clarifies something which was not completely clear in the Constitutional Treaty, namely, that the adjective 'delegated' or 'implementing' must be given in the title of the act. The Constitutional Treaty did contain these adjectives in the titles of the relevant articles (Delegated European Regulations and Implementing Acts in Articles I-36 and I-37, respectively), but did not state that these adjectives must be used in the names of the acts adopted. Since regulations could thus have been used for both delegated powers and purposes of implementation, the difference between the two could not be understood merely on the basis of the title of the act, but rather only after examining the enabling act.

54 See the explanation and examples given in nn 29-34 above.

55 While the Reform Treaty has inserted the words 'according to special legislative procedure' in many articles, in some cases it remains unanswered whether the act to be adopted is legislative or not; see, for example, Article 83 or Article 87/3(e). Acts adopted under these articles were designated by the Constitutional Treaty as non-legislative.

56 Except for Art 249c ToFEU, as proposed by the Reform Treaty, which states that implementing powers may be conferred on the Council 'in cases in Article I-40', thus referring to the article of the Constitutional Treaty that dealt with the CFSP. 
Council could adopt European decisions, ie acts that were categorised as non-legislative. The Reform Treaty deals with the entire CFSP area in a separate treaty, the TEU (more precisely, Chapter 2 thereof). This chapter mentions decisions as acts to be adopted in the CFSP area:

The Union shall conduct the common foreign and security policy by:

[...]

(b) adopting decisions defining:

(i) actions to be undertaken by the Union;

(ii) positions to be taken by the Union;

(iii) arrangements for the implementation of the decisions referred to in points (i) and (ii) ${ }^{57}$

However, it is not clear whether the term 'decision' in the CFSP area has the same meaning as a decision pursuant to Article 249 ToFEU, or is instead just a general expression for the outcome of a decision-making process. The new Article $17 \mathrm{TEU}$, as proposed by the Reform Treaty, expressly excludes the possibility of using legislative acts in the CFSP area. However, it remains a question what this exclusion of legislative acts really means, since legislative acts are defined in a formal way by reference to their procedure of adoption. As CFSP decisions are clearly not adopted through any of the procedures deemed legislative (either ordinary or special), this exclusion seems superfluous. However, if the term 'legislative act' is understood in a substantive sense, ie as an act wherein basic policy choices are made, this could considerably limit EU action in the CFSP area. Leaving the CFSP out of the new schema of EU legal acts is, therefore, probably a better reading of the Reform Treaty.

\section{Simplified?}

The new articles of both the Constitutional Treaty and the Reform Treaty obviously do contain some novelties with regard to how legal acts are organised in the text of the present Treaties. Does the system that the Member States wished to introduce under the Constitutional Treaty, and are now trying to introduce under the Reform Treaty, represent a simplification? Does it merely state in a simpler way, ie the way most understandable to EU citizens, the reality of EU decision-making and its outcomes? Or is the new organisation of legal acts the result of a new organisation of EU decision-making? If the latter, then this could mean that the relationship between EU institutions and the ways in which decision-making is legitimised have changed. The IGC can, of course, pro-

57 See the new Article 12 TEU, as proposed by the Reform Treaty. 
pose substantive, important changes; and indeed such changes can only happen based on Treaty amendments. Thus the second explanation of what is being offered by the Reform Treaty may also be possible. Yet if these changes are substantive, do they simplify the EU for European citizens? In the remainder of this paper, I will examine these questions with regard to the different types of proposed changes.

\section{Reducing the number of acts and redefining decisions}

Of the different changes that are or were on the table, the reduction of the number of acts seems to be one that would inevitably lead to a more understandable system. And indeed, I believe that simplification will result from this. However, not all the ways of reducing the number of acts necessarily represent simplifications.

Reducing the number of acts by merging acts of the same kind under a common name is simplification. One example of this is merging both a first-pillar directive ${ }^{58}$ and a third-pillar framework decision under the term 'directive'. ${ }^{59}$ Also, reducing the number of acts by eliminating some currently existing types that have not been widely used in practice likewise constitutes simplification. An example of this is the elimination of third-pillar conventions, ${ }^{60}$ which have disappeared not only in name but even as a type of act available to EU institutions. Finally, expanding the definition of an act to cover what has developed under that name in practice also involves simplification. The enlarged definition of a decision, which takes into account the development of non-Treaty acts called decisions yet not matching the definition of a decision under the EC Treaty, is an example of such simplification. Such reductions were, however, a logical consequence either of developments in practice or political decisions made in relation to other issues by the 2004 IGC or the Brussels European Council of June 2007. Thus the unification of first-pillar and third-pillar acts and the elimination of acts of an intergovernmental nature was possible because a political decision to submit third-pillar issues to the Community method had been reached. This reduction of the number of acts is, therefore, partly the result of textual adjustments to reality, but also of important decisions altering the balance of powers in the EU in today's third-pillar area.

On the contrary, reducing the number of acts by giving acts of different kinds the same name does not represent simplification. Such a move does not lead to a better understanding of the system; rather, it is misleading. Here I am referring to the CFSP area. The solution proposed

58 Currently Art 249 TEC.

59 Currently Art 34 TEU.

60 Currently Art 34 TEU. 
by the Constitutional Treaty was clearly to use decisions, defined as nonlegislative implementing acts, as the only instrument for the CFSP. Reducing the common actions and common positions available under the $\mathrm{CFSP}^{61}$ to just one instrument, especially one defined as broadly as decisions were defined in the Constitutional Treaty, is indeed simplification. However, using the same instrument for competences that are of a different nature, and thus regulated by different methods, is not. Using decisions as the sole legal instrument in the CFSP area, and as implementing acts in other fields, is more confusing than clarifying. Giving the same name to things that are different is not simplification.

The Reform Treaty solution is possibly better in terms of simplifying decision-making and legal acts in the CFSP area. But only 'possibly', because, as explained earlier, it is not clear how the Reform Treaty is to be read when it comes to the appropriate legal instruments in the CFSP area. ${ }^{62}$ However, it seems possible to interpret the proposed amendments related to legal instruments in the ToFEU as not being relevant to the CFSP. This allows for a decision as per the new Article $12 \mathrm{TEU}^{63}$ to be understood as an act additional to those enumerated in Article 249 ToFEU. For the sake of clarity, it would be better if decisions taken in the CFSP area were to have an attribute linking them to this area of EU competence, eg 'CFSP decision'. If, however, the new Article 249 ToFEU is not applicable to the CFSP area, then the decision mentioned in the new Article 12 TEU remains undefined except for its possible purposes, eg defining Union actions and positions, basic decisions, and implementation of such basic decisions. On whom and how such decisions are binding is not answered by the Treaty. Yet even if it needs further elaboration, the solution offered by the Reform Treaty concerning acts in the CFSP area seems better in terms of simplification, compared to what was offered by the Constitutional Treaty.

Some additional confusion may result from the new definition of a decision. ${ }^{64}$ It is obvious from the chosen definition that the intention was to retain one broadly defined and, therefore, flexible instrument which could be used to enact general decisions, and which would make recourse to non-Treaty instruments unnecessary. The first part of this definition thus states that it is an act binding in its entirety. It is also clear that a decision is also meant to be an act for individual decision-making. This

61 Currently Art 14 and 15 TEU, respectively.

62 See above following $\mathrm{n} 57$ in the main text.

63 See $\mathrm{n} 57$.

64 The new definition is the same in both the Constitutional Treaty and the Reform Treaty, with the significant difference, however, that in the Reform Treaty a decision may be used as both an implementing and a delegated act, while in the Constitutional Treaty it could only be used as an implementing act. 
is probably why the second part of the definition was added, specifying that a decision which specifies its addressees is binding only on those to whom it is addressed. Thus a decision without addressees is binding in its entirety on anyone, while a decision specifying addressees is binding in its entirety only on them. I fail to see the difference between a general decision and a regulation, except perhaps that the definition of a regulation presumes that it must be applied in the Member States (for it is written that it is directly applicable in all the Member States), thus making it inappropriate for deciding on internal institutional or inter-institutional matters of organisation. In that case, a comitology decision, for example (as envisaged in Art 249C para 3 ToFEU), would be more properly enacted in the form of a decision than a regulation. I also fail to see the reason for stating that a decision with addressees binds them in its entirety. This is obviously not meant to stress that the addressees are bound by decisions addressed to them, as that goes without saying. Also, the fact that a decision only binds its addressees cannot in itself exclude possible effects on third parties. Thus the reason for adding this sentence might be to avoid confusion between a decision addressed to the Member States and a directive, which is also, by definition, addressed to the Member States, yet binds them only as to the result to be achieved. This, however, is once again misleading, as a directive also binds, ie creates obligations for, the Member States in its entirety, as clarified by ECJ case law on the direct effect of directives. In conclusion, it would be much simpler if the authors of the Reform Treaty clearly stated that a decision is a binding act which may or may not specify its addressees, and which may be used as either a general or an individual legal act.

\section{Names of acts}

As explained in the previous section, the names of legal instruments were changed under the Constitutional Treaty, but have not been changed in the Reform Treaty. I have also already stated that I welcome the Reform Treaty's solution, and will now try to explain why (for the reason is not pure nostalgia). The real reason why the terms 'law' and 'framework law' have been excluded is explained in the IGC mandate:

The TEU and Treaty on the Functioning of the Union will not have a constitutional character. The terminology used throughout the treaties will reflect this change: (...) the denominations 'law' and 'framework law' will be abandoned, the existing denominations 'regulations', 'directives' and 'decisions' being retained. ${ }^{65}$

65 IGC Mandate (n 1) point 3, 16. 
Thus these names were dropped for exactly the opposite reason than explaining things clearly to EU citizens: they are part of a plan to persuade citizens that the EU does not have a constitution, even if it does have one. And all this for the sake of the new Treaty's success, which is obviously conditioned by citizens not having a say on it. Perverse, yet pragmatic.

However, the reason why I think that dropping the terms 'law' and 'framework law' is good is a different one: because they were misleading. In most Member States, the term 'law' is connected with an institution that is empowered to issue laws, that being exclusively a parliament. In the EU, the European Parliament does indeed participate in the creation of what is called European law, yet it shares this power with the Council. Furthermore, in the Member States the term 'law' not only points to a parliament but to the source of its legitimacy, ie the citizens who elect a parliament. What legitimises EU 'laws' is not only the citizens behind the Parliament, but also the Member States behind the Council. Sometimes it even seems, at least for the citizens of some Member States, that legitimacy deriving from the Council is more important than that deriving from the Parliament. The EU is acceptable today only if it satisfies such a demand for double legitimacy. However, as the term 'law' is linked with only one source of legitimacy, namely, the citizens represented in parliaments, using this term in an EU context is more misleading than clarifying. The term is even more misleading if one remembers that, due to still numerous exceptions, ${ }^{66}$ a law may be adopted by the Council alone, without the Parliament. On the other hand, there will most likely be fewer and fewer of these exceptions as integration evolves.

The concept of a framework law, in its meaning under the Constitutional Treaty, is even less familiar to European citizens. Such an act tells national parliaments what they ought to do. In the usual understanding of things, a parliament cannot be ordered to do anything by a law coming from anywhere but the parliament itself. ${ }^{67}$ European citizens are familiar with the concept of vague legislation that requires supplementation by another body - usually the government. In many Member States, parliamentary laws are so vague as to leave a lot to the government; however, this is the EU concept of delegation/implementation, not of a framework law. Thus the term 'framework law' is far from clear with regard to explaining its basic meaning to European citizens.

On the other hand, the EC/EU has existed for more than 50 years, and thus several generations of citizens have lived with it. Why should

\footnotetext{
66 See $\mathrm{n} 91$.

67 This does not mean that the actions of Parliament cannot be limited at all. Such limitations usually proceed from the constitutional norms of the polity.
} 
they not be familiar with names coming from Brussels like 'regulation' or 'directive', and be able to connect them with a real effect on their everyday lives? Many individuals have relied, or at least tried to rely, on such acts to enforce their rights in court. One need only remember the Variola brothers, ${ }^{68}$ Ms Marshall, ${ }^{69}$ Ms Faccini Dori, ${ }^{70}$ Ms Von Colson and Ms Kamman, ${ }^{71} \mathrm{Mr}$ Francovich, ${ }^{72}$ and so on. ${ }^{73}$ That the names 'regulation' and 'directive' are commonly known is possibly even truer in the new Member States. Much time and money was spent on teaching different actors in the new Member States what directives are, for example, and explaining their effects. Not only public servants and judges were involved in this, but many others, such as translators or journalists. In Croatia, months were spent just on finding the appropriate translation for the term 'directive'. ${ }^{74}$ Newspapers use these terms, as do politicians whenever they try to impress the public with the uncountable numbers of directives which have to be transposed in order to adjust to the acquis communautaire (people may even have learned the expression 'acquis communautaire!). It was wrong, therefore, to presume that citizens need names familiar to them from their domestic legal systems in order to understand, and that they are completely unfamiliar with the existing EU names.

One additional advantage of keeping the old names is to avoid the possible confusion which would result from regulations under the Constitutional Treaty. While regulations have always been perceived as the most law-like of EC acts, the Constitutional Treaty suddenly 'degraded' them into subordinate acts. More importantly, while regulations hitherto have been acts binding in their entirety and directly applicable in the Member States, the Constitutional Treaty opened the possibility for them also to be acts binding the Member States only as to the regulatory result, leaving them the choice of how to achieve such a result, and thus necessitating transposition. Finally, the Constitutional Treaty did not provide

68 Case 34/73 Fratelli Variola $v$ Ministry of Finance [1973] ECR 981.

69 Case 152/84 M.H. Marshall $v$ Southampton and South-West Hampshire Area Health Authority [1986] ECR 723.

70 Case C-91/92 Paola Faccini Dori $v$ Recreb Srl [1994] ECR I-3325.

${ }_{71}$ Case 14/83 Sabine von Colson and Elisabeth Kamman $v$ Land Nordrhein-Westfalen [1984] ECR 1891.

72 Joined Cases C-6 and C-9/90 Andrea Francovich and Danila Bonifaci and Others $v$ Italian Republic [1991] ECR I-5357.

73 For a different view, see HCH Hofmann, 'A Critical Analysis of the New Typology of Acts in the Draft Treaty Establishing a Constitution for Europe' (2003) 7(9) EIoP $3<$ http://eiop. or.at/eiop/texte/2003-009a.htm> accessed 24 July 2007. Hofmann considers that the names of EU legal acts, chosen to express the Union's non-state nature, give the impression that Europe is a matter for elites only, and therefore excludes its citizens from European affairs..

74 After all these discussions, a directive is called direktiva in Croatian! 
an answer as to what would happen to the numerous acts already existing as regulations, some of which would now have to be classified as laws, and others as regulations of the new Constitutional Treaty type. At the same time, some current directives would also have to be renamed as regulations.

In summary, the Reform Treaty's choice to retain the old names of legal acts is simpler. It is merely regrettable that one sound innovation of the Constitutional Treaty - namely, adding the attribute 'European' to the names of EU legal acts - has not been retained in the Reform Treaty.

Division into legislative/non-legislative acts, implied hierarchy and separation of powers

Both the Constitutional Treaty and the Reform Treaty have elected to make things more understandable to citizens by dividing legal acts according to the separation of powers among the institutions of government existing in European states. These acts were thus divided into legislative and non-legislative acts, thereby connecting them to the familiar notions of legislative and executive power. Legislative power in European states is associated with parliaments, and executive power with governments; and European models of the separation of powers have an in-built hierarchy in which the parliament is superordinated to the executive power, as the latter only executes the will of the former. In the Member States, the hierarchy of legislative acts (superior) and executive/non-legislative acts (inferior) is coupled with a hierarchy among the institutions enacting them, ie the parliament (superior) and the executive branch (inferior). The division of EU acts into legislative and non-legislative ones, therefore, necessarily has the consequence of creating the perception of a hierarchy not only among EU acts but also among EU institutions. ${ }^{75}$

However, the European Union system does not seem to be based on such a separation of powers. As already explained, there is no predesigned distribution of legislative functions to some institutions and executive functions to others. In fact, it is difficult to say which institutions in the EU are executive ones. ${ }^{76}$ Consequently, there is no pre-designed hierarchy among European institutions, either. As one author has stated, the EU system as it now stands is a system of functional checks and balances, rather than one relying on a single hierarchical chain that

\footnotetext{
75 Neither the Constitutional Treaty nor the Reform Treaty have, however, explicitly created a hierarchy among the enumerated acts.

76 See eg Deirdre Curtin, 'Mind the Gap: The Evolving EU Executive and the Constitution', $3^{\text {rd }}$ Walter Van Gerven Lecture (Leuven CCLE, 2004) <http://www.law.kuleuven.ac.be/ ccle/pdf/wvg3.pdf> accessed 3 August 2007.
} 
guarantees its democratic legitimacy. ${ }^{77}$ So attaching a higher rank in the hierarchy to acts emanating from certain institutions, simply because they emanate from these institutions, will lead European citizens to mistakenly assume that some institutions of the EU are superior to others. Therefore, in terms of simplification, the implied hierarchy among legal acts does not serve to bring the legal text in line with reality, as the reality is not hierarchical.

On the other hand, such a hierarchisation of acts may serve to actually bring about a clearer separation of powers and hierarchy among institutions. If this is so, the new organisation of legal acts would merely reflect the newly agreed separation of powers among institutions. And so the real reason behind this new organisation of acts might actually be to create a balance of powers on the EU level, similar to that existing in the Member States. If considered in terms of simplification, this could be justified by the fact that citizens are familiar with national systems of the separation of powers, and that creating the same or a similar system in the EU will help citizens understand the EU. In other words, if the EU model could be organised so that the European Parliament and the Council were perceived as legislators, and the Commission as the executive, citizens would understand it.

The link between the hierarchisation of acts and the creation of a hierarchy among institutions cannot be denied. Speaking as an expert for the Working Group on Simplification, Jean Claude-Piris explained that 'the customary distinction between legislative and executive authority, ie between some institutions empowered only to pass laws and others merely implementing legislation or issuing regulations' can only with difficulty be transposed to the Union without upsetting the existing balance between institutions. ${ }^{78}$ Therefore, reading the provisions relating to legal acts as reflecting a new type of relationship between EU institutions, based on some general principle distributing powers among them, would only be possible if such a new institutional balance were the result of a political agreement.

Leaving aside the fact that such oversimplification of functions is not possible (not only in the EU, but also in the Member States) and the discussion as to whether this would be appropriate for the Union at all, it will suffice here to note that such a political deal concerning a different distribution of powers among institutions does not seem to have been reached either at the 2004 IGC leading to the Constitutional Treaty or at the Brussels European Council which created the mandate for the cur-

77 B Crum, 'Legislative-Executive Relations in the EU' [2003] 41 JCMS 375, 380.

78 European Convention (Secretariat), 'Note summarising the meeting of Working Group IX (Simplification) on 17 October 2002' CONV 363/02 (Brussels, 22 October 2002) 8. 
rent IGC. In both the Constitutional Treaty and the Reform Treaty, EU institutions are still described in terms of their various functions, ${ }^{79}$ while their specific powers depend on the legal basis in a given policy area, which is to be found elsewhere in the Treaties. ${ }^{80}$ It is, therefore, impossible to know what the powers of the Commission, the Council and the European Parliament are without entering into concrete policy areas and the Treaty provisions regulating them. As Lenaerts and Desomer have said, 'the Court's ruling in France, Italy and the United Kingdom v Commission, denying the Union a general principle of separation of powers, still stands under the Constitution'. ${ }^{81}$ Although made in relation to the Constitutional Treaty, the authors would probably repeat this statement with regard to the Reform Treaty, as there are no significant differences between the two in terms of institutional provisions. One cannot locate any one general principle delimiting powers among institutions. Rather, the relationship and balance of powers between institutions still depends on the specific area of EU competence, and can be understood only by reading the relevant provisions of the Treaties. It does not seem, therefore, that the implied general hierarchy among legal acts can be explained by the desire to reorganise the EU's institutional structure of powers, and thus simplify things for EU citizens by making the separation of powers more similar to familiar divisions in the national setting.

The third possible reading of the division of acts into legislative and non-legislative ones could be that it only clarifies what is already the reality in the EU: namely, that there do indeed exist several levels of EU rule-making, and that there is a hierarchy among these levels. ${ }^{82}$ Legislative acts are thus the enabling acts, while non-legislative acts are always adopted on the basis of such acts, and so require the enabling provi-

79 The European Parliament and the Council are described as having legislative functions, among others. See, respectively, Art 9a and 9c TEU, as proposed by the Reform Treaty.

80 Hence the reference to other parts of the Treaties in the general opening articles on institutions. Pursuant to the Treaties, the European Parliament, for example, exercises functions of political control and consultation (Art 9a para 1 TEU, as proposed by Art 1 - 15) of the Reform Treaty); the Council carries out policy-making and coordinating functions (Art 9c para $1 \mathrm{TEU}$, as proposed by the Reform Treaty); and the Commission exercises coordinating, executive and management functions (Art 9d para $1 \mathrm{TEU}$, as proposed by the Reform Treaty).

81 K Lenaerts and M Desomer, 'Towards a Hierarchy of Legal Acts in the European Union? Simplification of Legal Instruments and Procedures' [2005] 11 ELJ 744, 764.

82 One successful example of using decision-making at several levels, and thus allowing for more technical decisions to be enacted into law by a simpler decision-making process, is the Lamfalussy Project on regulation of the EU Securities Market. In this respect, see EC Commission, 'Staff Working Document on the Application of the Lamfalussy Process to EU Securities Markets Legislation' SEC (2004) 1459, 15 November 2004. This project is already being implemented under the present constitutional framework of the EC Treaty, thus proving that decision-making by hierarchical levels does not necessitate Treaty changes, but only the political will of the institutions. 
sions in what are now called legislative acts. This does not change the reality, as the principle that an act adopted on the basis of another act must be in conformity with the latter in order to be legally valid already exists in the EU. ${ }^{83}$ Likewise, current case law already reserves the essential elements of an area for decisions by the institution(s) and under the procedures required by the relevant legal bases in the Treaties. ${ }^{84}$ The real question, then, is only whether the institution adopting the basic act has such a power under the Treaties, and whether the institution adopting the implementing act has such a power under the basic act, or else has exceeded the powers so granted. As acts adopted based on delegated powers need an enabling legislative act, and acts adopted based on implementing powers need an enabling legislative or delegated act, the implied hierarchy among acts in the new Treaty can be read simply as explicitly stating an already existing principle of EU law. The hierarchy thus introduced is, again, only a relational one, and there is nothing in the proposed text that would allow the reading of any hierarchy among non-legislative and legislative acts. Understood in this way, the articles on legal acts might have some simplifying effects, as they offer, in the text of the Treaties themselves, a judicially developed rule on relational hierarchy as one of the expressions of the principle of legality.

\section{Legislative versus non-legislative acts and democratic legitimacy}

As explained earlier, both the Constitutional Treaty and the Reform Treaty define legislative acts in a formal way, namely, as acts adopted in legislative procedure. This in and of itself does not clarify anything for European citizens, who are likely to ask: 'And - so what?' Since this definition lacks any substantive explanation that might distinguish legislative acts from other types of legal acts, and thus explain the purpose of this distinction, it is entirely superfluous, if not also confusing.

On the other hand, attaching to certain acts, and to them only, the quality of legislative acts must have some meaning, and must be meant to protect citizens' interests in a certain way. The answer is possibly hidden in the new Article 249b ToFEU, which relates not to legislative acts but to non-legislative delegated acts. The Article states that the essential elements of an area are to be reserved for legislative acts, and cannot be delegated. Such a substantive definition of a legislative act was proposed by the Convention's Working Group on Simplification. ${ }^{85}$ In an article pub-

\footnotetext{
83 See $\mathrm{n} 16$.

84 See Case 25/70 Köster (n 17).

85 According to the final proposal by the Working Group on Simplification, a legislative act was to be 'adopted on the basis of the Treaty and containing essential elements in a given field'; Working Group IX on Simplification (n 6) 9.
} 
lished after the Constitutional Treaty was signed at the IGC, Lenaerts and Desomer explained that the aim of reforming legal instruments under that Treaty was to 'rationalise the use of procedures and instruments in an increasingly political Union so that the basic policy choices in the EU legal order are taken according to the democratically most legitimate decision-making procedure' ${ }^{86}$

Of the existing procedures available, the co-decision procedure is the democratically most legitimate one, as only it gives the European Parliament a real decision-making power (even if this is still limited by the equal power of the Council). As the Parliament is the only body that can be controlled directly by European citizens, it is commonly held that democracy in EU decision-making can be increased by enlarging the decision-making powers of that body. In this way, the requirement for democratic legitimacy in a formal model of democracy is satisfied. If an act is adopted in a procedure which is deemed democratically legitimate, that act's legitimacy follows automatically. The form of adoption ensures the legitimacy of the act. Thus connecting the act with the adoption procedure increases the input legitimacy of EU legal acts.

The necessity for enhanced input legitimacy in the EU has been recognised in political theory. ${ }^{87}$ Stated in simple terms, the argument is that a polity is deemed legitimate if based on both input ${ }^{88}$ and output ${ }^{89}$ legitimacy. In different political systems, a different balance may be achieved between these two, but both need to be present. The legitimacy of current EU decision-making is usually explained only in terms of output legitimacy, ie citizens' approval of the outcome of the decision-making process is what has legitimised EU institutions. Such output legitimacy is substance- or results-based. It does not matter, therefore, whether it was the Council, the Parliament or the Commission which adopted an act, nor

\footnotetext{
86 Lenaerts and Desomer (n 81) 750. Democratic legitimacy was also a concern of the Working Group on Simplification, which stated that its task was "not only to make more comprehensible, but also to provide a guarantee that acts with the same legal/political force have the same foundation in terms of democratic legitimacy'; Working Group IX on Simplification (n 6) 2.

87 B Rittberger, 'Democracy and Accountability in the Enlarged European Union - The Development of European Parliament's Powers' <http://www.swp.berlin.org/common/ get_document.php?asset_id=830 $>$ accessed 3 September 2007. See also M Höreth, 'The Trilemma of Legitimacy - Multilevel Governance in the EU and the Problem of Democracy' (1998) ZEI Discussion Paper C 11 <http://aei.pitt.edu/340/> accessed 3 September 2007; and Heidrun Abromeit and Sebastian Wolf, 'Will the Constitutional Treaty Contribute to the Legitimacy of the European Union'? (2005) 9(11) EIoP <http://eiop.or.at/eiop/texte/200501 la.htm> accessed 3 September 2007.

88 Input legitimacy is achieved if decisions are made in a democratic process. It depends on the way in which decisions are made, not on the results which these decisions produce.

89 Output legitimacy is achieved if decisions solve citizens' problems effectively. It depends, therefore, on the results which these decisions produce.
} 
does it matter which procedure they used; what matters is whether a decision produces a result that is desirable, or at least acceptable, to citizens. On the other hand, the EU's input or democratic legitimacy is considered weak, as the usual modes of ensuring such legitimacy - popular interests represented in a national parliament, the democratic accountability of MPs - has been circumvented by the Member States' loss of control over EU decision-making. ${ }^{90}$ At the same time, the European Parliament's powers have not been designed so as to replace national parliaments in their legitimising roles. The procedure that comes closest to simulating this in the European Parliament is co-decision. Therefore, conditioning the possibility of enacting the most important decisions on the co-decision procedure increases input or democratic legitimacy, which is weak in the EU as compared to the Member States.

By coupling the most important decisions with the most democratic form of decision-making, the reorganisation of legal acts could possibly contribute to the EU's input legitimacy. However, if this is the aim of separating legislative from non-legislative acts, why is this not stated in the text of the Reform Treaty? Why do citizens need to read the article on delegated acts in order to understand that calling an act 'legislative' and defining it in terms of its adoption procedure are meant to ensure that the most important choices are adopted in a procedure over which they have the most influence? If the division into legislative and non-legislative acts really will increase the input legitimacy of EU decisions, it cannot be said that this will result from the simplicity with which it is explained to citizens in the new text of the Treaties.

Additionally, linking the new division of legal instruments to democratic legitimacy is complicated by the fact that some legislative acts are the result of procedures in which the European Parliament does not have a decision-making role (ie those for which the Reform Treaty uses the common name of 'special legislative procedures'). ${ }^{91}$ As explained by Lenaerts '[t]his choice reflects a rather realist and pragmatic approach which tends to suffer from a lack of democratic legitimacy, but which simply testifies to the particular sensitivity of those matters to some, if not all, Member States'. ${ }^{92}$ It is possible to treat special legislative procedures as

90 Thus some gain in input legitimacy will also be achieved through the involvement of national parliaments in EU decision-making, as proposed by the Reform Treaty and Protocol No 1 on the Role of National Parliaments in the EU.

91 Art 249a para 2 ToFEU, as proposed by the Reform Treaty. I have found 28 such instances in the text of the ToFEU (errors are possible, given the lack of a consolidated version of the Treaty at this point). The Council enacts legislative acts alone in special legislative procedure pursuant to the following articles of the ToFEU: 17bis/1; 18/3;19/1; 19/2; 20; 22/2; 69/3; 69D/3; 69F/2; 69I; 69J/3; 69L; 72; 93; 95; 97A; 104/14; 105/6; 137/2; $166 / 4 ; 175 / 2 ; 176 \mathrm{~A} / 3 ; 187 ; 229 \mathrm{~A} ; 266 ; 269 ; 270 \mathrm{~A} / 2 ; 270 \mathrm{~B}$.

92 Lenaerts (n 29) 58. 
an expression of political realism, and thus as a (temporary?) exception confirming the basic rule, ie the co-decision procedure for enacting legislative acts. However, this only confirms that the increased input legitimacy of the EU political system is the result not of a generally applicable division of acts into legislative and non-legislative ones, but rather of a political agreement to submit more areas of EU policy to the co-decision procedure.

One consequence of dividing acts into legislative and non-legislative is that the Council will be obliged to make its deliberations more transparent (public and published) ${ }^{93}$ when deciding on the draft of a legislative act. This in itself is a welcome novelty, as up till now the Treaties did not confine the Council to methods of decision-making that enable democratic control. Transparency of deliberations is envisaged by the Council's Rules of Procedure,${ }^{94}$ yet open meetings are only foreseen in the case of draft legal acts adopted in the co-decision procedure. ${ }^{95}$ After the Reform Treaty enters into force, the Council will have to open its meetings when discussing any legislative act, also including those adopted in a special legislative procedure. As already mentioned, it is not entirely clear whether all acts adopted by the Council alone, directly pursuant to the Reform Treaty but involving some participation by the European Parliament, represent legislative acts. (The Constitutional Treaty opted for some of these acts to be non-legislative.) If this question ever arises before the ECJ, it may be expected that the Court will opt for a solution whereby all such acts are categorised as legislative, as this would enhance democracy in the EU due to the Council's newly introduced obligation to hold open meetings. On the other hand, the exemption of non-legislative acts from the obligation to openness might prompt the Council to grant itself implementing powers more often so as to avoid public deliberations. The Reform Treaty allows this only in 'duly justified specific cases'. However, given the vagueness of that phrase and the unclear difference between legislative and non-legislative acts, which it is left to the legislator to decide, such attempts cannot be excluded. This is particularly likely in areas that still escape co-decision, since the European Parliament will not have a vote. At the same time, the very reason why the Parliament is excluded is due to the sensitivity of these areas for the Member States. ${ }^{96}$

\footnotetext{
93 In this respect, see Art 9C/8 TEU and Art 21a ToFEU, as proposed by the Reform Treaty.

94 Council Decision 2004/338/EC, Euratom of 22 March 2004 [2004] OJ L106/22.

95 Ibid Art 8

96 For example, Art 18 para 3 ToFEU, as proposed by the Reform Treaty, provides only for consultation with the European Parliament on the adoption of measures concerning social security and social protection which are necessary in order to attain the free movement of EU citizens.
} 
This may also be a reason for the Council to seek to discuss such issues secretly.

Linking the notion of legislation to the most important policy choices (or essential elements of an area, to use the Treaty's terminology) opens two additional questions. First of all, does this mean that other, less important issues may not be decided by legislative acts? Or, to put it differently, is the legislator limited by such a definition and forced to delegate less important issues to different processes and institutions? The present wording of the Treaty does not suggest this. Since everything but essential elements of a policy area 'may' be delegated to the Commission, this can be read to mean that anything may, first of all, be decided by legislative acts, that is, in legislative procedure. ${ }^{97}$ The choice of what should be delegated is to be made in the legislative process. While the legislator should exercise some self-discipline and not enter into too much detail in making legislation, it does not seem that binding him legally to concentrate only on essential elements is either useful or, indeed, verifiable in practice. ${ }^{98}$

The second question that remains unanswered is: which elements are essential? ${ }^{99}$ Obviously, this is not a question that can be answered generally and in advance for all policy areas in the EU's competence. Rather, it should be decided on a case-by-case basis. That said, one important issue remains open: namely, who is to decide what is essential and what is not? Obviously, it is the legislative process and its actors that can answer this question on each occasion. ${ }^{100}$ It is important to ask, however, whether their choice can be reviewed by the Court. Is the substantive part of the definition of a legislative act justiciable? In other words, can one submit to the Court the issue of whether the power to decide on an essential question has been delegated contrary to the Treaty, if determining what is essential depends on the political process itself?

\footnotetext{
97 'Anything' is, of course limited in the first place by the principle of conferral, and in the second place by the principles of subsidiarity and proportionality.

98 But see Lenaerts, who argues that legislative acts should be 'confined' to basic policy options (European Convention (n 78) 3). Indeed, some legal systems do limit the legislative function on a substantive basis. Thus, for example, Article 34 of the French Constitution enumerates what may be regulated by a law (loi). All other issues are left to the executive (according to Art 37 of the French Constitution: 'Les matières autres que celles qui sont du domaine de la loi ont un caractère réglementaire'). In this respect, see CM Alves, 'La hiérarchie du droit dérivé unilatéral à la lumière de la Constitution européenne: révolution ou sacrifice au nominalisme?' [2004] 5-6 CDE 691, who does not suggest transplanting the French model to the EU.

99 In this respect, see also Dougan (n 29) 784-785 and Hofmann (n 73) 10.

100 For the same opinion, see the Final Report of Working Group IX on Simplification (n 6) 10. The Working Group considered that the scope of essential elements or fundamental policy choices should be determined by the legislator on a case-by-case basis.
} 
In its existing practice, the ECJ has proved willing to judge what is and what is not essential. ${ }^{101}$ It has not, however, developed some general criteria according to which it decides such issues. Although in Case C-240/90 Germany $v$ Commission it stated that determining what is essential 'must be reserved for provisions which are intended to give concrete shape to the fundamental guidelines of Community policy', ${ }^{102}$ this statement is so abstract that one still cannot predict in advance which issues the Court will consider essential, and which not. It might be expected, however, that the Court, in accordance with the recent trend of deferring more to the political process, ${ }^{103}$ will choose a less intensive type of scrutiny and, for example, review only the formal side of such a decision, ie did the political institutions consider whether the delegated issue was essential at all? If so, the Court might choose not to enter into the substance of the issue, but simply trust that the political process is more suitable for finding adequate answers.

If the division into legislative and non-legislative acts does not create a hierarchy among legal acts, at least not an absolute one; if it does not reorganise, or result from the reorganisation of, the balance of powers among EU institutions; and if it does not in itself increase the level of democracy in the Union's decision-making process, citizens may then justifiably ask why it is in the Treaty at all.

\section{Delegated versus implementing acts}

Another puzzling division is that between non-legislative delegated and non-legislative implementing acts. The Reform Treaty (as the Constitutional Treaty before it) does not explain where the difference lies. Article 249b ToFEU, which deals with delegated acts, states the following:

1. A legislative act may delegate to the Commission the power to adopt non-legislative acts to supplement or amend certain non-essential elements of the legislative act. The objectives, content, scope and duration of the delegation of power shall be explicitly defined in the legislative acts. The essential elements of an area shall be reserved for the legislative act and accordingly shall not be the subject of a delegation of power.

The one thing that is clear is that delegation can happen only on the basis of a legislative act, which means that only the European Parliament

\footnotetext{
101 See eg Case 25/70 Köster (n 17) and Case C-240/90 Germany v Commission [1992] ECR I-5383. See also Case C-156/93 European Parliament $v$ Commission [1995] ECR I-2019.

102 Case C-240/90 Germany $v$ Commission (n 101) para 37.

103 Case C-112/00 Schmidberger Internationale Transporte Planzuge v Austria [2003] ECR I-5659.
} 
and the Council, together or separately, can delegate. It is also clear that they can delegate only to the Commission. The rest is uncertain. One such uncertainty concerns the status of acts adopted directly pursuant to the Treaties by the Council or the Parliament alone. If these are legislative acts, they may delegate to the Commission; otherwise, they may not.

The proclaimed purpose of delegation is to enable the Commission to "supplement or amend certain non-essential elements of the legislative act'. At the same time, the essential elements of an area cannot be delegated, but are reserved to legislation. The Commission can thus amend only the non-essential elements of an enabling legislative act. Nonetheless, in doing so the Commission will have to make complex policy choices, thus exercising a substantive power equivalent to legislative power. In this respect, it is not entirely clear why delegated acts are considered non-legislative rather than legislative acts. Likewise, the word 'delegated' suggests that the power transferred to the Commission is the same power which the 'legislator' possesses. Thus the Commission's power to amend non-essential elements of a legislative act is essentially a legislative power. ${ }^{104}$ The only difference is that the Commission cannot make policy choices concerning the 'essential elements' of a policy area.

Amending is one part of the definition of delegation; the other is 'supplementing' a legislative act. To supplement is obviously something different than to amend. Therefore, it must mean adding something to the existing provisions without changing anything in them. But what exactly can the Commission supplement? Is the power to supplement confined to non-essential elements of the legislative act, as might be concluded from the text of the provision, or can the Commission supplement both 'essential' and 'non-essential' parts of the enabling act? If supplementing means not changing, then there is no reason why the Commission should be prevented from also supplementing the 'essential' parts of the enabling act (provided that such a decision itself is not deemed 'essential').

However, if supplementing the basic act is a power the Commission acquires through delegation, what then is implementation all about? According to paragraph 2 of Article 249c ToFEU, as proposed by the Reform Treaty:

Where uniform conditions for implementing legally binding Union acts are needed, those acts shall confer implementing powers on the Commission, or, in duly justified specific cases and in the cases provided for in Article [I-40], on the Council.

104 In this respect, Craig argues that 'delegated regulations are only non-legislative in the formal sense that they are not primary laws. This does not mean that they are not legislative in nature.'; see P Craig 'The Constitutional Treaty: Legislative and Executive Power in the Emerging Constitutional Order' (2004) EUI-LAW Working Paper 7 p 32. 
There are two possible readings here. The first and less likely one is that implementation only means applying legal rules to individual situations. The only act appropriate for individual decisions is a decision as defined in Article 249 ToFEU, as proposed by the Reform Treaty. However, Article 249c, which deals with implementation, does not state that only implementing decisions may be adopted. Furthermore, the Constitutional Treaty, upon which the Reform Treaty is largely based, made it clear that acts of general application may also be adopted for purposes of implementation, and provided for the adoption of implementing regulations. This, together with the wording of the provision conditioning EU implementing powers on the necessity of assuring uniform conditions, calls for a different reading: implementation is not only about applying rules to individual situations, but also about supplementing basic rules by adopting additional general rules. The difference between such an activity and the supplementing of basic rules under delegation is beyond my power of discernment. Therefore, I can only conclude that delegation and implementation are the same activity, at least in part.

The notion of delegation is new to the EU legal order. Unlike implementation, it was proposed for the first time in the Constitutional Treaty. This does not mean that the Commission has not exercised delegated powers before now. Rather, both kinds of powers were called implementation; and implementation was performed on the basis of delegation, ie a delegating act specifying how the Commission could use the delegated powers. For although the Commission is often described as the EU executive, it does not enjoy any general implementing powers of its own. Rather, it only has specific powers of decision-making based directly on the Treaties, or the powers delegated to it by acts adopted by the Council alone or the Council and the Parliament together. The latter are based on Article 202 (third indent) TEC, which was introduced into the EC Treaty by the Single European Act. This provision contains a general rule granting the Council the power to delegate implementing powers to the Commission, and stating that the Council confers on the Commission powers to implement the rules it lays down. Since, in the course of time, the European Parliament has become a co-legislator in certain policy areas, the Council and the Parliament have sometimes jointly delegated powers of implementation to the Commission. Pursuant to Article 202 TEC, the Commission has often been empowered to enact rules of a general nature. ${ }^{105}$

105 In the area of competition policy, for example, the Commission has adopted several regulations on block exemptions based on Council Regulation 17/62 [1959-1962] OJ L87, replaced by Council Regulation 1/2003 [2003] OJ L1/1. These are Commission Regulation 2790/1999 on vertical agreements [1999] OJ L336/21; Commission Regulation 2658/2000 on specialisation agreements [2000] OJ L304/3; Commission Regulation 2659/2000 on research and development agreements [2000] OJ L304/7; and Commission Regulation $772 / 2004$ on technology transfer agreements [2004] OJ L123/18. 
Together with providing for the legislator's general power to delegate powers to the Commission, Article 202 (third indent) also envisages that such delegated power may be controlled by the delegating body based on general rules enacted in advance. These general rules enacted by the Council have become known as the Comitology Decision. ${ }^{106}$ These provide for three types of committees that are engaged with the Commission during decision-making, representing the Member States on an expert level and influencing the Commission's final decision. The committee management and regulatory procedures call for a planned implementing measure to be returned for decision by the Council should the committee vote against it (management procedure), ${ }^{107}$ or not vote for it (regulatory procedure). ${ }^{108}$ Two EU institutions have indicated their dislike of the comitology procedure: the Commission, because it limited its implementing powers, especially in the form of the regulatory committee procedure, and the European Parliament, because it has largely been excluded from controlling the Commission's implementing powers, even if it has gained real powers of co-decision with the Council in the meantime. ${ }^{109}$ One additional objection to comitology is its non-transparent and, therefore, undemocratic nature, ${ }^{110}$ which hides from the public what really goes on in the decision-making process, as the minutes of committee meetings are not made public in any way.

The new provision on delegated acts should probably be viewed in this light. The second paragraph of Article 249b ToFEU proposes different control mechanisms over the Commission when exercising delegated powers:

Legislative acts shall explicitly lay down the conditions to which the delegation is subject; these conditions may be as follows:

(a) the European Parliament or the Council may decide to revoke the delegation;

(b) the delegated act may enter into force only if no objection has been expressed by the European Parliament or the Council within a period set by the legislative act.

106 The first Comitology Decision was adopted in 1987 as Decision 87/373 OJ L197/33. It was replaced in 1999 by the Second Comitology Decision, ie Decision 1999/468 OJ L184/23 (n 13).

107 Art 4 of the Second Comitology Decision (n 13).

108 Art 5 of the Second Comitology Decision (n 13).

109 The Second Comitology Decision increased Parliament's powers in comitology by including the obligation to inform Parliament when the Commission transfers a proposal to the Council, and by allowing it to adopt a resolution when a draft implementing act exceeds the delegated mandate, if a measure was submitted to a committee based on an enabling act adopted in a co-decision procedure.

110 See eg R Dehousse, 'Misfits: EU Law and the Transformation of European Governance' (2002) Jean Monnet Working Paper 2 <http://www.jeanmonnetprogram.org/papers/02/020201.html> accessed 3 August 2007. 
Delegation and implementation thus do not differ substantively, at least not in the sense of enabling the Commission to enact provisions of a general nature in order to supplement the basic act. The two differ in the way in which the delegating body (or bodies) can control the Commission's exercise of the delegated powers. While comitology enables control of the Commission throughout the process leading to a final decision, the new control mechanisms for delegated powers provide only for ex post control. They leave more freedom to the Commission, and their efficiency as control mechanisms may prove less then the existing comitology model. ${ }^{111}$ If delegation is necessary in today's world of rapid changes and technological developments, since it allows quicker regulatory adjustments to real world demands, the reason why the institution primarily responsible for legislating will maintain control over such delegation is democracy. It is thus puzzling why that form of delegation closest to legislation is submitted to less democratic control than a form involving fewer policy choices, ie implementation. It seems that separating delegation from implementation represents a victory for the Commission in trying to establish itself as a self-standing EU executive. ${ }^{112}$

If this new model of control proves ineffective, it will not satisfactorily fulfil the European Parliament's demand for greater control over the Commission's delegated powers. From the Parliament's perspective, the better solution would seem to be keeping the old comitology system, which could then be adjusted to give more powers of control to the Parliament. This could be ensured by involving the Parliament in the enactment of a general comitology decision, which has indeed been done by the new Article 249c ToFEU with regard to implementation. ${ }^{113}$

Due to the lack of a substantive difference between delegation and implementation, coupled with a significant difference in powers of control over the Commission, the number of inter-institutional conflicts might increase, causing an additional overload for the European Court of Justice. The ECJ will then be forced to define the borderline between delegation and implementation.

111 Craig (n 104) 32-33.

112 Bergström considers that the new solution is indeed what the Commission has always asked for, but was rejected by the Council; see CF Bergström, Comitology, Delegation of Powers in the European Union and the Committee System (OUP, Oxford 2005) 354-355. Some scholars had argued in favour of giving, or, as they put it, 'returning' more powers to the European Commission through the IGC leading to the Constitutional Treaty. See eg J-P Jacqué, 'The Principle of Institutional Balance' [2004] 41 CML Rev 383, 391.

113 Art 249c para 3 ToFEU, as proposed by the Reform Treaty, envisages that in the future comitology-type decisions will be enacted together by the Parliament and the Council in ordinary legislative procedure. This article does not require in any way that the comitology system be retained. 
There is one more reason, this one of constitutional significance, as to why the line between implementation and delegation will have to be defined. According to the Treaty, the primary responsibility for implementing EU law lies with the Member States, not with Community institutions. ${ }^{114}$ The EU may implement only if 'uniform conditions for implementing legally binding Union acts are needed'. ${ }^{115}$ If it is necessary to secure uniform conditions of implementation, implementing powers may be conferred on the Commission or, only exceptionally, on the Council (in duly justified specific cases, to use the Treaty's words). By empowering the Commission (or the Council) to implement, the body granting such power $^{116}$ essentially deprives the Member States of their original power. Thus the question of the vertical (federal) division of powers between the EU and its Member States becomes relevant in the case of implementation. This is not the case with delegation, since by delegating their own legislative powers to the Commission, the Council and the Parliament are not depriving the Member States of their powers, but rather only delegating powers which already exist at the European level. The question of whether the EU legislator (the Council and the Parliament) possesses such legislative powers to be delegated is answered by the principles of conferral, subsidiarity and proportionality. Once it is clear that the EU has the power to decide on certain issues, the institution(s) to which such power belongs under the Treaty may delegate it to the Commission.

There is also one logical inconsistency in this entire construct. Namely, if implementing powers really belong originally to the Member States, it should be the Member States which delegate them to the Commission, not EU institutions. This may be resolved by saying that, where uniform conditions of implementation are needed, implementing powers belong to the EU level, and may therefore be exercised by the Commission.

By deciding that something is delegation, rather than implementation, EU institutions may, whether intentionally or not, disturb the vertical balance of powers designed by the Treaties. The delimitation between implementation and delegation newly introduced by the Constitutional Treaty, and taken over by the Reform Treaty, is thus far from simple.

\footnotetext{
114 The new Art 249c ToFEU, as proposed by the Reform Treaty, states in its first paragraph that 'Member States shall adopt all measures of national law necessary to implement legally binding Union acts'.

115 The new Art 249c para 2 ToFEU, as proposed by the Reform Treaty.

116 It seems that implementing powers may be granted by any type of EU act, ie not only by legislative acts. This means that not only the European Parliament and the Council but also the Commission itself may grant the Commission implementing powers.
} 


\section{Conclusion}

What was proposed by the Constitutional Treaty, and remains on the table under the Reform Treaty, with regard to the legal instruments which EU institutions use when they decide on EU policies cannot be described as simplification. Neither does it present the existing system of EU legal acts in a more user-friendly way, nor has it changed the system substantively in a way that is more understandable to EU citizens and explained this adequately in the new Treaty.

The biggest novelty is the introduction of the distinction between legislative and non-legislative acts. However, even if such a distinction has been nominally introduced, in substantive terms the four relevant articles of the ToFEU (Articles 249 - 249c) do nothing more than state what has already developed in EU practice. The division between legislative and non-legislative acts does not reorganise, or result from a reorganisation of, the balance of powers among EU institutions. It does not create a hierarchy among legal acts, at least not an absolute one. Most importantly, it does not, at least not in and of itself, increase the level of democracy in the European Union's decision-making process. Democracy will indeed increase by submitting more areas of EU policy to co-decision (renamed as 'regular legislative procedure'). However, the division of acts into legislative and non-legislative was not the condition for such an increase in the level of democracy.

This apparently new system is new not in substance but only in name, and the name is actually wrong because it is misleading. It is misleading primarily because it describes the EU using terminology common within the Member States' legal and political systems, whereas the organisation of EU decision-making and the legitimisation of its decisions do not follow the same model. The Reform Treaty has not changed this. The chosen terminology is additionally confusing because some of the terms have been used hitherto in EU matters with a different meaning: for example, the term 'legislation' has simply meant acts of general application; ${ }^{117}$ or, to take another example, the term 'implementation' has been used to denote what is called both 'implementation' and 'delegation' in the Reform Treaty ${ }^{118}$ (moreover, the new Treaty does not clearly explain the difference in substance between these two). It is clear that the procedures for monitoring implementation and delegation differ, yet it is unclear, at least in terms of democracy, why more freedom is left to the Commission under delegated than under implementing powers.

117 See eg Case 160/88 R Fedessa v Council [1988] ECR 4121 para 27: 'It has also consistently stated that the criterion for distinguishing between a measure of a legislative nature and a decision is whether or not the measure at issue is of general application.'

118 Cf Jean-Claude Piris, The Constitution for Europe. A Legal Analysis (CUP, Cambridge 2006) 73. 
At the same time, the new articles on legal acts have not solved some genuine problems which citizens face when confronted with EU acts. This refers primarily to the confusing doctrine of the direct or indirect effect of directives, which causes uncertainty as to whether citizens do or do not have certain rights. Yet as the offspring of judicial practice, it may also need to mature in such practice, and not in the political and constitutional process.

There are, however, some simplifications in the new Treaty. For example, the number of legal acts has been reduced. While this results from the reorganisation not of legal acts themselves, but rather of the pillar structure, it is still a welcome development. If one compares the Constitutional Treaty with the Reform Treaty in terms of simplicity, the latter is better because, if nothing else, it retains the old names for EU legal acts. On the other hand, certain useful solutions from the Constitutional Treaty have not been transferred to the Reform Treaty, such as adding the attribute 'European' to the names of EU legal acts. 